https://doi.org/10.15407/socium2020.01.138

UDC 336:69:330.35

Bublyk Ye.O., PhD. (Economics), Senior Researcher, Department of Monetary Relations, SO "Institute for Economics and Forecasting, National Academy of Sciences of Ukraine", 26, Panasa Myrnoho Str., Kyiv, 01011, Ukraine, email: bubl13@gmail.com, ORCID iD: https://orcid.org/ 0000-0002-6080-9341

\title{
DEVELOPMENT FINANCE INSTITUTIONS AND THEIR ROLE IN INCREASING EFFICIENCY OF CAPITAL FLOWS
}

The article dwells upon modern approaches to determining the prospects of cooperation with specialized financial institutions for development in the interests of supporting economic growth. It is noted that the negative attitude to the prospects of cooperation with the financial aid institutions does not deny their potential. The modern economic relations give reasons to consider development finance institutions as a promising direction for rationalizing the financial openness of economies with an underdeveloped market environment. Involvement of development finance institutions into the economic policies, in the framework of special state programs, is able to extend the capacity of overcoming structural and functional defects of the underdeveloped financial sector that are immanent for the transitive economies. Cooperation with the financial institutions for development helps to overcome information asymmetry, to strengthen competition, to grow market institutions and implement non-speculative counter-cyclical measures for innovative development and industrialization. Paper analyses characteristics of cooperation between Ukraine and international development financial institutions. Also, author offers possible directions of maximizing the effectiveness of international financial support through the activities of national development finance institutions. The functionality and perspective directions of interaction of such institutions, tools and necessary prerequisites for raising their productive activity have been substantiated. Among this, the primary focus should be made not on the redistribution of financial resources, but rather on the intensification of attracting investment funds for the state economic development programs. Important functions of national development institutions at this stage are: establishing information and organizational support for international investment projects in Ukraine in order to develop the institutional environment of the financial sector, to restore investment attractiveness and to streamline the structure of financial openness.

Keywords: development finance institutions, financial openness, international capital flows, economic development, foreign direct investment.

Бублик $\boldsymbol{C . O . , ~ к а н д . ~ е к о н . ~ н а у к , ~ с т а р и и и ̆ ~ н а у к о в и и ̆ ~ с п і в р о б і т н и к ~ в і д д і л у ~ г р о ш о в о - к р е д и т н и х ~}$ відносин ДУ “Інститут економіки та прогнозування НАН Украӥни”, вул. Панаса Мирного, 26, Kü̈в, 01011, Україна, email: bubl13@gmail.com, ORCID iD: https://orcid.org/0000-0002-60809341

\section{ФІНАНСОВІ ІНСТИТУТИ РОЗВИТКУ ТА ЇХ РОЛЬ У ПІДВИЩЕННІ ЕФЕКТИВНОСТІ ПОТОКІВ КАПІТАЛУ}

Узагальнено сучасні підходи до визначення перспектив взаємодіі із спеціалізованими фінансовими інститутами розвитку в інтересах підтримки економічного зростання. Зазначено, щзо критичне ставлення до перспектив взаємодї з інститутами допомоги не

(C) Bublyk Ye.O., 2020 


\begin{abstract}
заперечує їхньому потенціалу. Розвиток сучасних економічних відносин дає підстави розглядати фінансові інститути розвитку як перспективний напрям раціоналізації фінансової відкритості економік з несформованим ринковим середовищем. Залучення фінансових інститутів розвитку до реалізації економічної політики в рамках спеціалізованих державних програм здатне розширити можливості подолання структурно-функціональних недоліків недорозвиненого фінансового сектору транзитивних економік у частині вирівнювання інформаційної асиметрії, усунення недоліків конкуренції, вирощування ринкових інститутів, реалізацї̈ неспекулятивних контрциклічних заходів інноваційного розвитку та індустріалізації. Проаналізовано характер співпраці України з міжнародними фінансовими інститутами розвитку та визначено напрями максимізації ефективності міжнародної фінансової підтримки через діяльність національних фінансових інститутів розвитку. При иьому обтрунтовано функціонал та перспективні напрями взаємодї таких інститутів, інструментарій $і$ необхідні передумови забезпечення їх продуктивної діяльності через першочергову орієнтацію не на перерозподіл фінансових ресурсів, а на інтенсифікацію залучення інвестиційних коштів у рамках державних програм розвитку економіки. Важливими функціями національних інститутів розвитку на изьому етапі $\epsilon$ налагодження інформаційноорганізаційного забезпечення міжнародних інвестиційних проєктів в Україні з метою розвитку інституціонального середовища фінансового сектору, відновлення інвестиційної привабливості та раціоналізації структури фінансової відкритості.
\end{abstract}

Ключові слова: фінансові інститути розвитку, фінансова відкритість, міжнародні потоки капіталу, економічний розвиток, прямі іноземні інвестиції.

Capital accumulation is an objective prerequisite for economic growth. Despite this, the use of national or attracted from abroad capital by commercial banks on free flow market conditions in an open economy leads to its productive transformation into investment resources only in limited extent. The reason is, in particular, that choosing from a wide range of financial instruments, private institutions favour those that are most liquid and costeffective. This is entirely justified in terms of business interests, but capital investments usually are not related to such instruments. From this point of view, the use of development finance institutions may lead to expanding of possibilities for targeted attraction of the most productive forms of international capital flows (ICF) including FDI, targeted loans or financial aid that correspond to the interests of national economy development.

The issue of productive allocation of financial resources in the scientific literature receives considerable attention both from economists of developed countries (P. Mosley [1], A. Deaton [2]), and developing ones, which rely on financial assistance attraction (V. Heyets [3], V. Kolosova [4], Yu. Kindzerskii [5], V. Massa [6]). Due to ongoing efforts to overcome the aftermath of the global financial crisis and restore economic growth with the help of development finance institutions (DFI) in small economies with emerging markets, this issue is receiving new attention, and the topic of DFI is undergoing renaissance.

The aim of the article - defining the role and significance of the development financial institutions to rationalize the process of the financial resource base expansion for the small open economies.

Recent research findings in the field of analyzing the characteristics of FDI flows visually demonstrate the problem of the economic impracticality of a significant proportion of world's FDI flows. Almost half of world's FDIs is used not to promote real economic 
activity, but to avoid taxation and the concealment of offshore capital and illicit capital laundering [7]. The unproductive nature of a large proportion of foreign investment necessitates the development of a special state investment framework in order to maximize the inflow of real capital into prospective industries and infrastructure sphere.

This way of transformation of FDI role in the economy at the present stage confirms that productive capital is mostly determined not by the type of instrument, but by the real content of the financial transaction, which results in the development of production factors: fixed assets, technologies, human capital, infrastructure, etc. In this case, any type of instrument: FDI, portfolio investment or bank loans may cause the productive capital build-up. The main condition is that financial resources support the provision of socio-economic development projects and the creation of new businesses. In this context, optimizing the inflow of foreign capital means to increase its productivity component.

An alternative to non-targeted FDI that do not have a positive impact on the institutional development of small open economies approach is to target the inflow of foreign capital through government interaction with relevant international development financial institutions (IDFIs). IDFIs could be defined as organizations that perform the function of financing of socio-economic development projects that unlikely to be fully financed by private business. Main acting goals of IDFIs are: providing state development programs, activating investors attraction, technical support and assessment of the efficiency of socio-economic projects; support of the investments by long-term loans and others.

Collaborating with IDFIs and participating in mutually beneficial conditions in international projects opens the prospect for attracting real financing for the modernization of the country in all kinds of direction: from the improvement of financial market institutions to the development of human capital. However, in the context of increasing globalization and its impact on the development of transformational economies, the mechanism of realization of the state investment policy, which should represent national interests through implementation of sharing strategy of investments and carrying out the corresponding policy of institutional transformations, becomes especially important.

At the outset it should be noted that there is a rather radical, albeit corroborated by numerous global experiences, that IDFI's assistance, having some positive effect on the micro level, does not have a productive impact on the macro level, or may even be proved as harmful if it demotivates governments from reforming and feeding corruption [1]. Indeed, in the absence of proper development of market institutions, lack of political will and consistency in the implementation of government development programs, the positive effects of such assistance may be absent at the state level. However, this does not mean the irrationality of attracting foreign financial assistance. As the problem lies in the underdeveloped market environment and the limited motivation of the government to pursue development programs persistently [3]. Actually, exactly under these circumstances the need for specialized DFIs activity increases. They can act more confidently in the face of market instability and provide fundings in the presence of the political will of the government, which is manifested through accelerating procedures for the development and implementation of relevant investment projects. In the absence of such a will, with open credit lines and framework agreements, the volume of real financing will remain low. 
An analysis of the nature of the modern economic relations development due to the prospects of the DFI's potential exploiting gives reasons to consider them as a necessary stage of rationalization of the economies financial opening process with a distorted market environment. Indeed, the involvement of DFI in the implementation of economic policy may help to overcome the structural and functional deficiencies of the transformation economies underdeveloped financial sector. They may act for equalization of information asymmetry, elimination of competition deficiencies, growing of market institutions, and implementation of low-profit operations for counter-cyclical measures. Numerous scientific and expert studies generally confirm the correlation of DFIs investment activity and the growth of individual macroeconomic or institutional indicators: job creation, technology transfer, market institutions and environment development, sustainability of financial institutions, etc. For example, a $10 \%$ increase in IDFI's commitments correlates with a $1.3 \%$ increase in the GDP of low-income economies [6, p. 6]. And, according to EBRD experts, 58\% of investment projects implemented in the period 2004-2009 are highly successful [8].

The largest international development finance institutions include the IMF, the World Bank Group and four regional development banks: European, African, Asian and InterAmerican. An interesting example is the Asian Infrastructure Investment Bank (ABI), with a capital of $\$ 100$ billion [9]. Its establishment as a regional development bank in 2015 was argued, in particular, by the fact that the world most extended IDFIs operate with insufficient financial resources and their allocation is burdened by additional political and economic requirements ${ }^{1}$.

Despite the wide list of institutions open for cooperation and signed agreements on cooperation, Ukraine's involvement in attracting their investments is not very productive and the volume of used financing is limited. The indicators of Ukraine's cooperation with the World Bank speaks for itself. The indicator of World Bank loans usage over the entire cooperation period ranges from 30 to $40 \%$. In particular, in the middle of 2019 , a record $39.1 \%$ was reached after a significant reduction in 2014-2017. Ukraine's cooperation with the EBRD looks better: the same indicator for the same date was $48.5 \%$, while for other institutions: $\mathrm{EIB}-17.7 \%, \mathrm{KfW}-4.9 \%{ }^{2}$.

Traditionally, the most profitable sectors of the Ukrainian economy, such as energy, have been the driver of growth in attracting investments. There are 11 projects in this area. The main goal of major projects is to improve the safety of nuclear power units. Funding for projects in this area was the largest indicator of usage: 50-70\%. There are 9 and 6 projects in the field of transport and public utilities, respectively. The financial sector, social sphere and education have only 1-3 projects. Usage for projects in these industries maintained at $30-40 \%{ }^{3}$.

Main potential advantages of DFI' interaction. In the context of a warped market environment, national development finance institutions are called upon to promote targeted investment in specialized industries, markets (entities) performing a number of functions

\footnotetext{
${ }^{1}$ Asian Infrastructure Investment Bank. URL: https://www.aiib.org/en/about-aiib/index.html

${ }^{2}$ The Cabinet of Ministers of Ukraine. URL: https://www.minfin.gov.ua

${ }^{3}$ The same.
} 
including information support. In this case, the inherent properties of National Development Financial Institutions (NDFIs) have a number of advantages:

- the activities of such institutions are designed to provide funding for the most promising areas of structural reform of emerging markets economies with the prospect of attracting foreign capital for these purposes;

- the interaction of a network of such institutions at the sectoral, national or international levels makes it possible to implement a set of public policy measures to achieve the goals of sustainable economic growth;

- in the process of interaction at the international, regional and local levels, the NDFIs are able to consistently receive sufficient large amounts of long-term fundings;

- by the involvement in top-level international or state policies, NDFIs get enhanced opportunities to work in an underdeveloped institutional environment and information asymmetries.

It should be noted that after the thirty-year period of globalization in the format of neoliberal consensus, development institutions are experiencing a renaissance period, affirming their utility in the area of public policies for economic development [4]. It is in the wake of the effects of the global financial crisis that both research and regulatory policies have once again drawn attention to the "decisive potential" of NDFIs in providing countercyclical impact, filling gaps in market infrastructure, targeting promising areas of financial market development, and financing structural reforms. In the most extent, the activities of the NDFI support the UN, noting that the introduction of new NDFIs, as well as the expansion of existing ones, are being undertaken both by developed and developing economies [10]. Surprisingly enough, in the wake of liberalization, India has decided to close its development banks by relying on the stock market [11]. The works of IMF's experts are paying more attention to international development banks, noting that they can play a vital role in mobilizing private sector funding [12].

The importance of the NDFIs and advanced economies is being given increasing importance, contrary to popular belief that full-fledged capital markets and commercial banking systems in high-income countries are depriving the economy of its need for government support. In various regions, DFIs account a fairly large proportion of banking assets: South Asia - 12\%, South America - 10\%, Germany - 8\%. In the Germany, the Credit Recovery Institute (KfW) is among the TOP-10 banks in the country and is among the largest EU issuers [13]. The implementation of these functions in world practice embodies a wide list of NDFIs with relevant specialization.

An important role of the NDFIs is also given at the regional interstate level. For example, the EU since 2014 emphasizes the need to support the implementation of the Investment Plan for Europe by the effective support activities of national support banks to enhance their impact on investment, growth and employment through their specific experience and knowledge of the local context, business and investor community in accordance with national policy and strategy [14]. And the United Nations Industrial Development Organization has even developed a partnership strategy with the NDFI to provide financial support for its investments and enhance their productive impact locally [15]. 
At the beginning of 2019, the total number of institutions that could be assigned to their function and tasks to the NDFIs numbered 442 institutions in 147 countries. At the same time, $25 \%$ of NDFIs are located in Africa, 20\% in Europe, 20\% in America, 31\% in Asia and $4 \%$ in Oceania [16]. This list includes both development banks and insurance / guarantee / financial institutions. This number is much higher than the World Bank statistics, which lists only 90 development banks in 61 countries and reflects the true value attached to this type of institution in the world.

Trends in the NDFIs renaissance in the world can be explained by the awareness of the irrationality of investor behaviour in the context of information asymmetry. Under such circumstances, the problem of balancing information asymmetry and supplying reliable data to the markets and the responsibility for the information providing is of particular relevance. NDFIs called to address these challenges for the market in general and in cooperation with IDFIs. The advantages of attracting funding from international DFIs are that the receiving of financial resources from them mostly does not require radical financial liberalization. In the stages of low financial openness, most developing countries actively cooperate with regional financial development institutions.

Conditions for increasing the economic effects of interaction with the DFIs. It should be noted that the activities of IDFIs alone do not lead to an effective impact of their investments on the growth of the macroeconomic indicators of the recipient countries. In this regard, it is quite reasonable to recognize the position of the Nobel laureate A. Dieton, that without appropriate economic policies, which are being deliberately implemented by the government in the interest of improving the welfare of the population, any kind of international financial assistance may even hamper economic development [2]. The presence of such a positive influence can be seen only in some examples of countries that combined the involvement of international financial assistance with the activities of the NDFIs in the interests of implementing relevant economic policies. In this case, NDFIs should act as the transmission link between the profit-oriented ICF and the national interests formulated in the framework of economic development programs.

Therefore, the NDFI should be considered as special economic entities created at the state initiative and under its financial and material support for special aims. NDFIs could be fully or partially state-owned. They used to be a special tool for maintaining the integrity and stability of the entire economic system of the country, to overcome the existing market mechanisms failures, regulating the economy in the priority areas of national interests [5, p. 62].

The reasons for the low actual results of Ukraine's cooperation with the IDFIs lie in the context of an underdeveloped internal institutional environment of financial sector and systemically weak government initiative. Productive allocation of foreign capital attracted from IDFIs to support economic growth and quality development of the institutional environment is possible by providing ICFs originating from IDFIs through the relevant NDFIs in interests for inclusive development. This scheme of interaction opens the prospect for increasing the impact of the ICFs on economic development (see Figure. 1). 


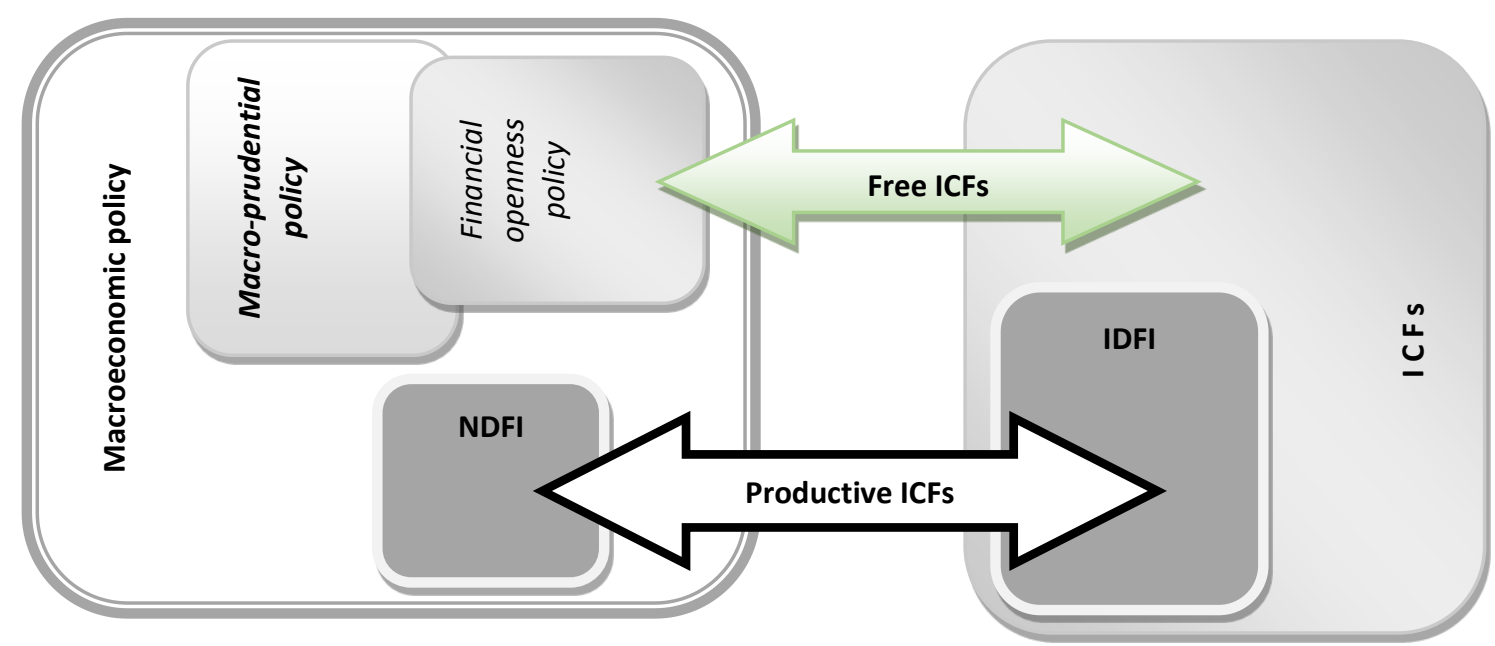

Source: Developed by the author.

Fig. 1. Institutional scheme for streamlining ICFs

However, due to the weakness of the domestic stock market, only bank lending to energy efficiency projects with participation in their DFI financing has become widespread in Ukraine. Successful in this sphere is the practice of Ukreximbank, which has been cooperating with international DFIs for over 20 years. In addition, 12 of them are in the field of sustainable energy financing products development. In 2007, the Bank entered into the first loan agreement with the European Bank for Reconstruction and Development (EBRD) the Ukrainian Energy Efficiency Program with more than $\$ 50$ million. Following the successful implementation of a number of projects, the EBRD extended the limit for $\$ 50$ million more in December 2008. Moreover, in 2012 it further increased funding by another $\$ 50$ million. All three tranches of the program have been successfully used by the bank ${ }^{4}$.

It should be noted that due to the legislative changes adopted in 2019 aimed at improvement of the creditors' rights protection, stabilize macroeconomic conditions and reduce the interest rate, the prospects for extending credit products for energy efficiency in the Ukrainian banking market are increasing. Other banks also demonstrate successful use of DFI programs for energy efficiency, but are mostly taken by individuals, much less by entrepreneurs. It is worth mentioning the activities of the recently established Energy Efficiency Fund in Ukraine, which cooperates with the International Finance Corporation (IFC), Deutsche Gesellschaft für Internationale Zusammenarbeit (GIZ) and the United Nations Development Program (UNDP).

Thus, despite the wide potential availability of open for cooperation IDFIs, the implementation of their projects in Ukraine through interaction with the state-owned Ukreximbank is more positively characterized. This institution, by its function, is focused on supporting domestic exports and serves as the NDFI. This fact clearly demonstrates that the

\footnotetext{
4 Ukreximbank. URL: https://www.eximb.com/ua/business/financial/realizovani-proekty/proekt-zenergoefektivnosti-zi-svitovim-bankom/
} 
way to maximize the productive impact of foreign financial assistance lies through the organization of interaction between international and national development financial institutions.

Defining of functional priorities for NDFIs. After summarizing the list of these advantages, it should be noted that NDIFs might have a profile orientation, depending on their tasks: development of industries, financial sector or different social spheres. They may be created on a public-private basis to ensure the accumulation of long-term private investment, project financing or targeted assistance for the development of a profile area.

In the conditions of limited budget resources of the Ukraine an important function of development institutions is not only, and not so much, direct financing and economic activity, as socio-economic control. The essence of this approach is that the implementation of socio-economic control ensures the equalization of information in an underdeveloped institutional environment of financial sector and forms important prerequisites for the proper formation of such environment. According to experts of the World Bank, examples of such control are [17]:

- protection of property rights, the rule of law and reduction of corruption in the conditions of insufficient development of these institutions;

- overcoming information asymmetry and proper information support for investors in conditions of imperfect competition;

- regulation of the level of competition in the markets;

- informing new market participants about the rules of ownership;

- ensuring proper regulation of financial markets to avoid their imperfection;

From time to time macroeconomic stabilization tasks also may be added to the DFI' functions [16, p. 14]:

- support for macroeconomic and national currency stability;

- prevention of poverty growth, civil conflicts and negative cyclical fluctuations in the economy.

Functions of information support of national development financial institutions, in cooperation with international capital flows can be specified as follows:

- providing expertise on the status of the profile industry or market to potential lenders, procedural consultations, reporting to the public and international partners;

- active participation in the profile development programs and related prospective investment projects;

- search for sources to attract foreign investment;

- accumulation of financial resources under public-private partnership.

The importance of securing precisely the function of socio-economic control in the field of efficient allocation of foreign investment resources within the framework of the regulating financial openness policy in terms of ensuring inclusive economic development of the country is subsequent upon the analysis of previous attempts to use these institutions in Ukraine and other developing countries. Numerous attempts to create relevant institutions in Ukraine: UBRD, State Mortgage Vehicle, Export-Insuring Agency, etc. proved to be unsuccessful as they focused immediately on the functions of redistribution of financial resources received from the state in the conditions of an unformed institutional environment 
[18]. Without necessary institutional capacity and independence, these institutions implemented counter-productive corruption-based initiatives, discontinued and discredited the idea of development institutions.

Instead, these institutions should performe the redistribution of financial resources during the next stages of their activity. At the first stage, they should ensure the foundation of institutional enviroentment for the productive formation of the target segment (financial market, industry, etc.), meaning: increasing the confidence level in the market, the effectiveness of protection of property rights and interests of participants, information support, strengthening competition, strengthening the role of self-regulatory organizations. Based on the current world experience, the conditions for ensuring the effective operation of the NDFIs are:

- proper consolidation of the basic function parameters with maximization of the acceptable level of independence of the NDFIs, fixed by the law;

- the priority of social functions over economic and business interests;

- independence or indirect dependence on state bodies and the possibility of functioning with attraction of private and foreign capital;

- defined specialization of NDFIs by economic purpose, business direction or market segment;

- ensuring permanent state attention and comprehensive support;

- implementation of a quality control system for the efficiency of the NDFI's action on the percentage of successfully implemented projects, attracted capital and ensuring the fulfilment of socio-economic objectives.

In this context, even the activity in sustainable marking of usefull for economy development sectors as "permitted" or "encouraged" should be recognized as useful; it may signal investors a constant desire to attract foreign capital into them.

In view of the existing cooperation programs signed by Ukraine and the needs of its economic development, the following activities of the NDFI are particularly promising: credit financing of the real sector of the economy (in the SME sector) and infrastructure projects. The fact is that these areas coincide with the priority investment areas of the WB and the EBRD and Ukraine already has agreements for financing with them. Other areas include: support for exporters, funding for science and innovation programs, support for the sustainable development of the financial sector. In the absence of effective NDFIs, insufficient attention from the line ministries and state regulatory bodies leads to the limited usage of international funding for the support of Ukrainian development projects. This situation applies even to IMF financial programs.

Conclusions. The organization of cooperation with the IDFIs through the NDFIs, within the framework and directions of national economic development programs, opens significant prospects for ensuring the rationalization of financial openness and maximizing the positive impact of foreign capital inflows and financial assistance on shaping conditions for productive economic growth. Confirmation of the need for the implementation of the NDFI is the extending of IFI-approved attitudes toward them, which were sceptical before the global crises. Such change in attitude confirms the conceptual transformation of institutional perspectives on the reasonability of implementing the ICF regulation policy, which can be 
noted as the need to enhance the usage of the free movement of the ICF in the interests of economic development.

At this stage, the rationalization of the financial openness of the Ukrainian economy with the participation of the NDFIs is to intensify the attraction of IDFI investment funds in projects of socio-economic development. The main aim of the NDFIs activity is the prospect of eleminating the existing gaps in the financial sector's institutional environment and focusing on support of the development and ensuring the investment projects in Ukraine. Supporting the rational improvement of the financial openness of the Ukrainian economy in this direction requires creation and restoration of a complex of proper functioning specialized NDFIs. Acting of NDFIs requares adequate regulatory support with defined independence limits, priority of social goals, permanent attention of the government, the involvement into government programs and quality control of the their effectiveness.

Despite the traditional threat of turning development institutions into low-functional, bureaucratic, corrupted organizations, the prospects for their development in Ukraine seems to be really significant. In order to prevent the realization of aforementioned threats, the development of such institutions should be established at the legislative level. The legislatively prioritized functions of socio-economic development through support for the implementation of relevant state programs should narrow the window of opportunity for non-targeted activities. The determination, in the possible extend, their institutional independence will increase their responsibility and will ground the requirements for the reporting and professional quality of their management.

The most important condition for reducing corruption risks is to restrict access to the real financial flows of such institutions in the first stages of their activity. In the first stages, active work of the NDFIs in the field of information support, searchimg for investors, substantiation of the necessary investment projects and marking them, the organization of public-private partnerships and, within certain limits, the operation of state guarantees, is able to increase the productive potential of the international capital flows into the country.

\section{References}

1. Mosley, P. (1986). Aid-effectiveness: The micro-macro paradox. Ids Bulletin, 17 (2), 22-27. https://doi.org/10.1111/j.1759-5436.1986.mp17002004.x

2. Deaton, A. (2016). Great escape. Health, Wealth, and the Origins of Inequality. Moscow: Izd-vo Instituta Gaidara [in Russian]

3. Heyets, V.M. (2015). To the question of application of the approaches of the "Marshall plan" in Ukraine. Ekonomika Ukrainy - Economy of Ukraine, 4, 6-11 [in Ukrainian]

4. Kolosova, V.P. (2016). Influence of international financial organizations on country's economic development: theoretical questions. Ekonomika Ukrainy - Economy of Ukraine, 12, 61-71 [in Ukrainian]

5. Kindzerskii, Yu. (2010). Development institutions: principles of formation and problems of use in economic transformations. Obshchestvo i ekonomika - Society and Economics, 7-8, 57-78 [in Russian]

6. Massa, I. (2011). Impact of multilateral development finance institutions on economic growth. Overseas Development Institute. URL: https://www.odi.org/sites/odi.org.uk/files/odi-assets/publicationsopinion-files/7312.pdf

7. Damgaard, J., Elkjaer, T., Johannesen, N. (2019). The Rise of Phantom Investments. Finance \& Development, 56, 3. URL: https://www.imf.org/external/pubs/ft/fandd/2019/09/the-rise-of-phantom-FDIin-tax-havens-damgaard.htm 
Bublyk Ye.O.

8. Annual evaluation overview report for 2009. (2009). EBRD. URL: https://www.oecd.org/ derec/ebrd/48480830.pdf

9. Nassiry, D., Nakhooda, S. (2016). The AIIB and investment in action on climate change. Working Paper 433. URL: https://www.odi.org/sites/odi.org.uk/files/resource-documents/10441.pdf

10. Transforming our World: The 2030 Agenda for Sustainable Development. (2015). URL: https://sustainabledevelopment.un.org/post2015/transformingourworld/publication

11. Calcagno, A.F., Dullien, S., Márquez-Velázquez, A., Maystre, N., \& Priewe, J. (Eds.). (2015). Rethinking development strategies after the financial crisis. United Nations. URL: http://unctad.org/en/PublicationChapters/gdsmdp20151fas_en.pdf

12. Broccolini, C., Lotti, G., Maffioli, A., Presbitero, M.A.F., Stucchi, R. (2019). Mobilization effects of multilateral development banks. International Monetary Fund. Working Paper, 19/28. https://doi.org/10.5089/9781484393864.001

13. Rethinking the Role of National Development Banks. (2006). United Nations. URL: https://www.un.org/esa/ffd///////wp-content/uploads/2006/11/20061122_NDBs-MSC-SA-Report-

DRAFT-1206.pdf

14. Working Together for Jobs and Growth: The Role of National Promotional Banks (NPBs) in Supporting the Investment Plan for Europe. (2015). URL: https://eur-lex.europa.eu/legal-content/ $\mathrm{EN} / \mathrm{TXT} / \mathrm{PDF} /$ ?uri=CELEX:52015DC0361\&from=EN

15. Addis Ababa Action Agenda of the Third International Conference on Financing for Development (Addis Ababa Action Agenda). (2015). United Nations. URL: https://unctad.org/meetings/en/ SessionalDocuments/ares69d313_en.pdf

16. Xu, J., Ren, X., Wu, X. (2019). Mapping Development Finance Institutions Worldwide: Definitions, Rationales, and Varieties. Institute of New Structural Economics Peking University. https://doi.org/10.13140/RG.2.2.31323.62240

17. World Economic Outlook: Growth and institutions. April 2003. (2003). IMF. URL: https://www.imf.org/ external/pubs/ft/weo/2003/01/

18. Bublyk, Ye.O. (2011). Mortgage market in Ukraine: problems and prospects of post-crisis development: monograph. Kyiv: Institute for economics and forecasting, NAS of Ukraine [in Ukrainian]

Received on 02.03.20 